PART 2

National Case-Studies 
Iain Fenlon - 9789004311824

Downloaded from Brill.com04/26/2023 08:45:31AM via free access 


\title{
Lost Books of Polyphony from Renaissance Spain
}

\author{
Iain Fenlon
}

The books of printed and manuscript polyphony that survive in the libraries of Spanish cathedrals, collegiate churches, and monasteries represent only a small fraction of what must have originally existed. ${ }^{1}$ That much is clear from inventories, which survive in some number and which, in some cases, offer sufficient detail to allow titles and editions of printed books to be accurately identified. Other types of documentation, such as notarial records, contracts, correspondence, and Actas Capitulares (the latter being a particularly rich source for the purchase of music by cathedrals and donations), help to augment the picture. Occasionally, copies acquired by both institutional libraries and private collectors in more recent times carry indications of provenance that connect them to their original owners. ${ }^{2}$ By bringing together evidence from this rich and variegated documentary base augmented by surviving copies, it is possible to acquire not only some sense of the processes of the

1 Much of the information presented in this article was gathered in the course of the research project 'Music, Print and Culture in Spain and Portugal during the Renaissance', funded by a personal grant from The Leverhulme Trust and based at the Faculty of Music, University of Cambridge. Tess Knighton was employed as a full-time research assistant on the project during its initial phase and, thanks to a grant from the Banco Bilbao Viscaya Argentaria, the work benefitted enormously from the advice of Emilio Ros Fabregas during a term that he spent as a visitor. References to surviving copies of printed books of music follow the system used by the Recueils imprimées des sources musicales, Einzeldrucke vor 180o, 14 vols. to date (Kassel: Bärenreiter, 1971-) [henceforward RISM]. The starting point for any consideration of sixteenth-century inventories of books of polyphony is the fundamental article by Emilio Ros Fábregas, 'Libros de música en bibliotecas españolas del siglo Xvı', Pliegos de bibliofilia, 15 (2001), pp. 37-62, 16 (2001), pp. 33-46, and 17 (2001), pp. 17-54.

2 There are many such cases. For one example, see the copy of Tomás Luis de Victoria's Officium hebdomadae (Rome: Alessandro Gardano, 1585) [RISM 1432] now in the British Library (shelfmark k.9.c.14), which contains the contemporary inscription "Da livr[raria] da Novicia de S[an]ta Cruz de Coimbra" [f. Aii]. The book was acquired by the British Museum in 1864. For sixteenth-century printed editions that were once at Santa Cruz see Owen Rees, Polyphony in Portugal c. 1530-c. 1620: Sources from the Monastery of Santa Cruz, Coimbra (New York and London: Garland, 1995), pp. 87-97 and, for the dispersal of the library after the suppression of the religious orders in Portugal in 1834, pp. 5-9. Ms. 44, still in Coimbra, bears an identical inscription. 
transmission and dissemination of printed music seen within the general context of the early-modern Iberian book trade, but also to put back into the historical account of the repertories performed in individual institutions the many books of music that were once used but have been lost through time, theft, neglect, and war.

The general practice in Spanish institutions was that books of music, both chant and polyphony, were kept in both the sacristy and the choir. Everyday responsibility for their care was usually entrusted to one of the senior mozos de coro, who carried them to and from the choir as needed. ${ }^{3}$ Typically, chants for the complete liturgical year were professionally copied into a series of large folio choirbooks which were brought into use according to the time of year and their place in the calendrical cycle. ${ }^{4}$ Often illuminated and decorated with penwork cadels, ${ }^{5}$ they were usually bound in heavy wooden boards with metal clasps, reinforced corners, and bosses designed to protect the covers. Throughout the sixteenth century and beyond, polyphonic codices continued to be copied into custom-made vellum polyphonic choirbooks notwithstanding the widespread circulation of printed books most of which were imported; among the collections that survive, those of Toledo Cathedral are remarkable for both their repertorial range and extent. ${ }^{6}$ In functional terms, the spatial arrangement of the typical Spanish coro, constituted as an enclosed structure placed in the centre of the nave and usually finished on its eastern side with an elaborate wrought-iron screen, facilitated the performance of both chant and polyphony from a lectern facing the High Altar (see fig. 4.1). Despite the emphasis placed upon increased accessibility to and visibility of the central sacral area in the decrees of the

3 See, for example, the following extract from the Constituciones of the Chapel Royal of 1584 : "Los mozos de capilla, saliendo ésta a alguna parte fuera de palacio, en servicio de S.M., sean obligados a llevar y volver los libros de canto y ponellos en su lugar y si en esto fueren negligentes no ganen distribución y sean penados en dos reales", as transcribed in Emilio Casares (ed.), Francisco Asenjo Barbieri: Documentos sobre música española y epistolario (Legado Barbieri) (Madrid: Fundación Banco Exterior, 1986-1988), vol. I, no. 161, at p. 53.

4 For a characteristic example of a single collection, that of Málaga Cathedral, see María Julieta Vega Garcia-Ferrer, Los cantorales de canto llano en el Catedral de Málaga (Granada: Junta de Andalucia, 2007) and, for the largest collection of indigenously produced plainsong manuscripts, Michael Noone and Graeme Skinner, 'Toledo Cathedral's Collection of Manuscript Choirbooks: A Preliminary Report and Checklist', Notes, second series, 63 (2006), pp. 289-328.

5 See J.J.G. Alexander, The Decorated Letter (London: Thames and Hudson, 1978), p. 27 and plates XXIX and Xxx.

6 Michael Noone, 'A Manuscript Case-Study: The Compilation of a Polyphonic Choirbook', in David Fallows and Tess Knighton (eds.), Companion to Medieval and Renaissance Music (London: Dent, 1992), pp. 239-246. 
Council of Trent, this traditional arrangement continued in many places, and choirbooks both manuscript and printed continued to be produced for the Spanish market both locally as well as elsewhere in Europe.

Other kinds of books might be kept in a chest below the lectern in the choir, while smaller format breviaries and other liturgical books in constant use were often chained to the choirstalls to prevent their disappearance. One of the duties of the maestro di capilla, who had overall control of the choir and the choir school, was to ensure that the books of polyphony were kept safe and in a decent condition; it was partly to ensure this that periodic inventories were called for by the chapter, particularly at the point when one chapelmaster relinquished his post and another took charge. Inventories were also commonly made in relation to pastoral visits, and on occasions when the chapter had reason to believe that the books were not being properly protected. A documented episode from the cathedral of La Seo in Zaragoza gives the flavour of such concerns. On 14 August 1653 the chapter ordered that the music should be placed

in a cupboard...and that it should be inventoried and handed over to the care of whoever the sacristan might be....and that the day before the feast on which the music is needed, the musicians should ask the canon who holds the key for what is required for that day, and above all he should ensure that they...return [it] to the cupboard once it has been sung. ${ }^{7}$

Inventories relating to both the acquisition and preservation of printed books of polyphony are one of the main sources of information about books which no longer survive. A typical example of their utility is provided by documents in the Archivo Capitular of Tarazona Cathedral, which still houses one of the most substantial collection of printed books of music from the sixteenth and early-seventeenth centuries in any Spanish ecclesiastical institution, as well as seventeen manuscripts from the same period. ${ }^{8}$ The importance of a number of these contemporary inventories was first recognized in the nineteenth century, ${ }^{9}$

7 Antonio Ezquerro Esteban and Luis Antonio González Marín, 'Catálogo del fondo documental del siglo Xviı del Archivo de las Catedrales de Zaragoza', Anuario Musical, 46 (1991), pp. 127-171, pp. 127-128, and Pedro Calahorra Martínez: Música en Zaragoza. Siglos XVI-XVII (Zaragoza: Institución Fernando el Católico, 1977-1978), vol. I, p. 102.

8 Justo Sevillano, 'Catálogo musical del Archivo Capitular de Tarazona', Anuario Musical, 26 (1961), pp. 149-176; Julián Ruiz Izquierdo, José Antonio Mosquera and Justo Sevillano Ruiz, Biblioteca de la Iglesia Catedral de Tarazona. Catálogo de libros manuscritos, incunables y de música (Zaragoza: Institución Fernando el Católico, 1984).

9 Vicente de la Fuente, Las santas Iglesias de Tarazona y Tudela en sus estados antiguo y moderno (Madrid: s.n., 1865-1866). 


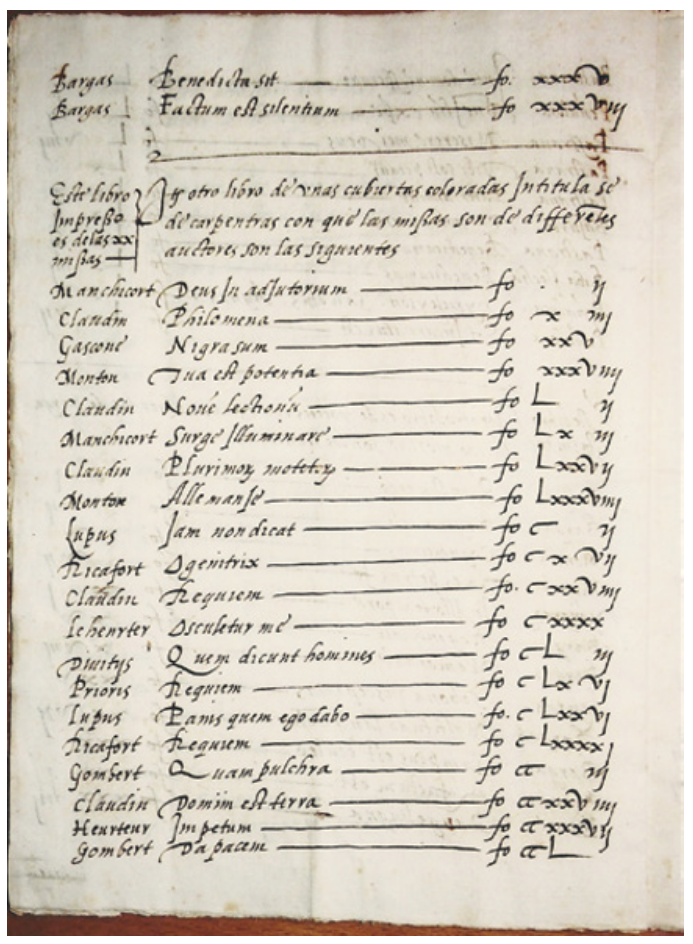

illustration 4.1 Tarazona Cathedral, Memoria c. 1619.

and since then both these and others that have since come to light have received a good deal of scholarly attention. ${ }^{10}$ The earliest is undated, is almost certainly incomplete, and contains detailed listings of twenty-five books of music. A second, more extensive inventory, the Memoria of c. 1619, includes almost all the books listed in the first, together with a further sixty-eight items. The rubric at the end of the first part of this second inventory indicates that it is based in turn on an earlier inventory, now lost, of 1570 ; a second inventory from later in the sixteenth century is also missing. The Tarazona inventories correspond only in part with the editions of printed music that have survived, and while some are listed that have now been lost, others that are extant are not recorded. In consequence, correlation between the entries in the Memoria and the books surviving in Tarazona is only possible because of the nature of the descriptions, which extends to listing the contents of both printed and manuscript

$10 \quad$ For the latest studies see Pedro Calahora Martinez, 'Los fondos musicales en el siglo XVI de la Catedral de Tarazona. I. Inventarios', Nasarre, 8 (1992), pp. 9-56; Fábregas, 'Libro de música', no. 57 . 
volumes in some bibliographic detail. Another consequence is that most of the volumes that have disappeared can be identified from their descriptions; they include editions of masses and motets by Clemens non Papa, ${ }^{11}$ the seven magnificent choirbooks containing a total of twenty Masses published by Pierre Attaingnant in $1532,{ }^{12}$ the book of five masses by Carpentras, ${ }^{13}$ a book of motets by Eliseo Ghibellini, ${ }^{14}$ and a book of six-voice motets by Adriano Willaert. ${ }^{15}$

Also listed is "un libro de cubiertas coloradas de quince missas de dibersos auctores" whose contents are described in detail. From this it is clear that this was a manuscript copy of a substantial part of the Liber quindecim missarum, a choirbook printed by Andrea Antico in Rome (a title that was widely disseminated throughout the Iberian Peninsula), with more recent repertory added. ${ }^{16}$ Despite the frequency with which Antico's choirbook appears in Spanish inventories, only one copy of the book is known to survive in the whole of Spain, in the archive of the Iglesia-colegiata in the small town of Pastrana. ${ }^{17}$ As a collection the Liber quindecim missarum was extraordinarily long lived, largely

11 The mass volume would have been one of the series issued by Pierre Phalèse in Leuven in 1556 (RISM C2666-2683). Similarly, the part-book edition of the motets would most probably have been one of those published by Phalèse (RISM C2685-2707) with the Quintus liber modulorm quinque vocum ([Paris]: Simon du Bosc, 1556) [RISM C2685] as an outside possibility.

Daniel Heartz, Pierre Attaignant, Royal Printer of Music: A Historical Study and Bibliographical Catalogue (Berkeley: University of California Press, 1969), nos. 33-39, pp. 245-249 [RISM 1532/1-1532/7].

13 Liber primus missarum (Avignon: Jean de Channay, 1532) [RISM G1571].

14 Two published editions of Eliseo Ghibellini's five-voice motets are known. The first, with the title Motetta super plano cantu cum quinque vocibus...liber primus, produced by an unnamed printer appeared in Venice in 1546 [RISM G1770]. The second, a re-edition of the first, entitled Motectorum...cum quinque vocibus liber primus, was published by Girolamo Scotto in 1548 [RISM G1771]. It would seem more likely that Tarazona cathedral owned the Scotto edition since this, according to Jane Bernstein, Music Printing in Renaissance Venice: The Scotto Press (Oxford: Oxford University Press, 1998), no. 69, pp. 361-363 has 24 leaves, which agrees with the inventory description.

15 Presumably the Musicorum sex vocum, que vulgo motecta dicuntur...liber primus (Venice: Antonio Gardano, 1542) [RISM W1112]. According to Mary Lewis, Antonio Gardano, Venetian Music Printer 1538-1569: A Descriptive Bibliography and Historical Study (London: Garland, 1988-2005), vol. I, no. 34, pp. 343-347, this has 24 leaves, which matches the inventory description.

16 Liber quindecim missarum (Rome: Andrea Antico, 1516) [RISM 1516/1].

17 Details of the design of the binding of this copy, which carries the arms of the Duke of Pastrana, suggests that it was acquired or at least used for performance in the early seventeenth century, possibly during the period after the death of the third duke in 1626, when the archbishop of Sigünza, Pedro González de Mendoza (d. 1639) became a major patron 
because of its value as a collection of masses by Josquin which continued to be performed throughout the sixteenth and seventeenth centuries. ${ }^{18} \mathrm{~A}$ rubric at the end of one of the Tarazona inventories reveals that it was common practice for books that had become too worn to be recopied and then discarded, and that new music was copied into blank pages in some of the existing books. In these circumstances some later manuscripts, where they have survive, provide the physical evidence for the existence of copies of earlier printed books which do not.

Although few institutional collections are so well inventoried, often such information can be supplemented by other types of documentation. In the case of Burgos Cathedral, an inventory of books kept in the sacristy in 1560 makes only one reference to books of polyphony ("quatro libros de musica de canto de organo"), ${ }^{19}$ but acquisitions are occasionally recorded in the chapter acts. ${ }^{20}$ Among the references that can be picked up in this way is an entry for September 1541, when the Archdeacon of Treviño, in the province of Burgos, gave three books of polyphony to the cathedral, including "one of twenty masses and another of fourteen and another of ten" which a week later were handed over to the chapelmaster, Rodrigo de Ceballos, for safekeeping. ${ }^{21}$ The first of these is almost certain to have been, as in the case of Tarazona, a complete set of Attaingnant's folio choirbooks which together provide twenty mass settings as advertised on the title-page of the first volume of the series, ${ }^{22}$ while the third is probably Moderne's Liber decem missarum, another folio choirbook which was widely circulated in Spain. ${ }^{23}$ Some twenty years later

of a number of ecclesiastical institutions in Pastrana and took a direct interest in their musical activities.

18 The Pastrana copy of the Liber quindecim missarum does not appear in a list of the music books made in 1557, but is recorded in the Memoria of 1654; see Carlos Martinez Gil, Catálogo de música del Archivo Parroquial (Antigua Colegiata) de Pastrana (Guadalajara) (Universidad de Salamanca, Cursos de Doctorado, Bienio 1993-1994, unpublished), pp. vii-ix.

19 Ros Fábregas, 'Libros de musica', no. 46.

20 For the surviving sources see Demetrio Mansanill Reoyo, Catálogo de los códices de la Catedral de Burgos (Madrid: Instituto Enrique Florez, CsIC, 1952); Demetrio Mansanilla, Archivo Capitular de la Catedral de Burgos: breve guía y sumaria descripción de sus fondos (Burgos: Ediciones Aldecoa, 1956); José López Calo, La música en la catedral de Burgos, 3 vols. (Burgos: Caja de Ahorros del Círculo Católico, 1996).

21 López Calo, La música en la cathedral de Burgos, nos. 78, 347-348.

22 Primus liber viginti missarum musicalium (Paris: Attaignant, 1532); see Heartz, Pierre Attaignant, pp. 245-249, nos. 33-39 [RISM 1532/1-1532/7].

23 Samuel F. Pogue, Jacques Moderne: Lyons Music Printer of the Sixteenth Century (Geneva: Droz, 1969), pp. 117-122. For the distribution of Moderne's choirbooks see my article 
Francisco Guerrero wrote to the chapter in January 1572 concerning some books of music that he was sending to the cathedral: "ciertos libros de música de misas e magnificas y motetes". ${ }^{24}$ This practice of sending books of printed music to cathedral chapters in the hope that they would be purchased outright or recognized by some form of pourboire was common. ${ }^{25}$ By this date the composer had published one book each of masses, motets, and magnificats, and it would seem that it was these, rather than a manuscript containing a selection of his works, that he was dispatching to Burgos. ${ }^{26}$ None of these books now survive, and what must have been a typical collection of choirbooks and partbooks of polyphony to complement the usual set of cantorales is now represented by just one volume, Juan Navarro's collection of psalms, hymns and magnificats, published in Rome in $1590 .{ }^{27}$

The importance of musical provision at the primatial cathedral in Toledo is evident from the rich archival documentation that has survived. ${ }^{28}$ The importance of this material, which includes not only a number of book inventories but also records of book purchases, has been acknowledged by a number of historians, beginning with Felice Rubio Piqueras who was the first to describe the collection in print. ${ }^{29}$ Even earlier, Francisco Asenjo Barbieri had transcribed various inventories of the music library together with payment documents

'Jacques Moderne's Choirbooks and the Iberian Music Trade', forthcoming in the book of memorial essays for Frank Dobbins.

24 López Calo, La música en la cathedral de Burgos, nos. 165, 715.

25 Among other Spanish composers Tomás Luis de Victoria used this practice extensively after his return to his native country in $1585^{-1586}$. See Alfonso de Vicente, Tomás Luis de Victoria: Cartas (1582-16o6) (Madrid: Fundación Caja Madrid (Los siglos de oro), 2008).

26 Namely, the Liber primus missarum (Paris: Nicholas du Cemin, 1566), the Canticum Beatae Mariae (Leuven: Phalèse, 1563), and three editions of the motets [RISM G4866; G4867; G4871].

27 Juan Navarro [Psalmi, hymni ac Magnificat totius anni, secundum ritum Sanctae Romanae Ecclesiae, quatuor, quinque ac sex vocibus concinendi, necnon Beatae Virginis Dei genitricis Mariae diversorum temporum antiphonae in finem horarum dicendae] (Rome: Francesco Coattino, 1590); this copy lacks all before fol. 4 (ff. 1-2) are supplied in manuscript (sec. XVII ${ }^{\text {ex}}-X V I I I^{\text {in }}$ ) [RISM N283].

28 François Reynaud, La polyphonie tolédane et son milieu des premiers témoignages aux environs de 1600 (Tours: CNRS Editions, 1996).

29 Felice Rubio Piqueras, Música y músicos toledanos: contribución a su estudio (Toledo: Establecimiento Tipográfico de Sucesor de J. Peláez, 1923); Felice Rubio Piqueras, Códices polifónicos toledanos: estudio crítico de los mismos con motivo del VII Centenario de la Catedral Primada (Toledo: s.n., 1925). See also Robert Stevenson, 'The Toledo manuscript polyphonic choirbooks and some other lost of little known Flemish sources', Fontes Artis Musice, 20 (1973), pp. 87-107. For a richly-illuminated manuscript whose existence was 
relating to purchases. ${ }^{30}$ Michael Noone has recently described and analysed a number of sixteenth- and seventeenth-century inventories, some of which have not been previously published, of the printed music. ${ }^{31}$ Taken together, these different kinds of evidence reveal a large number of editions of music that were known to have been owned by the cathedral but which have now disappeared, including Andrea Antico's ubiquitous Liber quindecim missarum, music by Morales (probably the two books of masses), Victoria's Hymni totius anni and his Cantica B. Virginis, Navarro's psalms, and a good deal of music by Guerrero. $^{32}$ In repertorial terms none of this is particularly surprising. Less expected is the presence of books of polyphony printed some fifty years before their acquisition, notably the three editions of Sebastián de Vivanco's music, one volume each of magnificats, masses, and motets issued by Artus Taberniel in Salamanca between 1607 and 1610, but acquired by the Toledo chapter as late as $1658 .{ }^{33}$ The persistence of stile antico liturgical polyphony in Spanish institutions is not in itself a novelty; it is evident from both surviving sources and inventories that music by Palestrina, Morales, Guerrero and Victoria, the staples of the international Catholic repertory, continued to be acquired throughout the seventeenth and eighteenth centuries, and that it was performed, in what is a continuous tradition, as late as the twentieth, until the Second Vatican Council brought the practice to a halt. It is more of a surprise perhaps to find music by a local composer still in circulation so long after it was printed.

Different again is the case of Córdoba Cathedral, which occupies a somewhat unrivalled position in the architectural history of Spanish ecclesiastical institutions due to its extraordinary amalgamation of Moorish and Christian elements. Following the reconquest of the city in 1236, the Great Mosque was re-founded as a cathedral and duly consecrated. Chapels and other Christian architectural and decorative elements were gradually added to the building, but it was only in the sixteenth century that the bishop and chapter found royal support for the erection of a cathedral transept, including choirstalls. This entailed demolition of part of the mosque, an action that was bitterly

known to Stevenson but which could not then be consulted see Robert Snow, 'Toledo Cathedral Ms. Reservado 23', Journal of Musicology, 2 (1984), pp. 246-277.

30 Casares (ed.), Francisco Asenjo Barbieri, I, p. 401 (inventory of 27 March, 1563, drawn up by Bernardino Ribera), p. 231 (inventory of 24 September 1590, drawn up by Alonso Gascón), and p. $55^{8}$ (inventory of 30 April 1793, various extracts).

31 Michael Noone, 'Printed Polyphony Acquired by Toledo Cathedral', in Iain Fenlon and Tess Knighton (eds.), Early Music Printing and Publishing in the Iberian World (Kassel: Edition Reichenberger, 2006), pp. 241-272.

32 See Appendix 1 below.

33 Noone, 'Printed Polyphony', pp. 264-265. 
opposed by the city but supported by Charles v; at his instigation building work began in September 1523. The alterations, which clearly had important ramifications for the celebration of the liturgy and the performance of polyphony, were not finished until 1607. Stimulated by the completion of the choir stalls in that year, the regular performance of polyphony became established. ${ }^{34}$ As part of the general account of the cathedral's goods made in connection with a pastoral visit by the Visitor General in April 1629, an inventory was made of the books of music, both printed and manuscript, formerly in the care of the maestro de capilla. Most of these contain polyphonic repertories of Vespers and Mass music by Spanish, Portugese, and Flemish composers, together with works by Josquin, Lassus, Palestrina and others. ${ }^{35}$ Further details emerge from payment documents. In March 1566 Guerrero presented a copy of his first book of masses to the chapter, and about a month later the chapter agreed to pay him an honorarium. ${ }^{36}$ In June 1622, a book of music by Duarte Lobo was presented in a similar way to the chapter. Sadly, only six of the books in the list are still extant; all are choirbooks most of which have lost their title-pages through use:

Guerrero, Francisco: Missarum liber secundus (Rome: Domenico Basa/ Francesco Zanetti, 1582) [RISM G4872].

Lobo, Alonso:Liber primus missarum (Madrid:Johannes Flandre, 1602) [RISM L2588].

[Lobo, Duarte]: [Cantica Beatae Maria Virginis] (Antwerp: Ex officina Plantiniana, 1605). [RISM L2590].

[Lobo, Duarte]: [Liber missarum] [Antwerp: Ex officina Plantiniana, 1621] [RISM L2591].

[Rogier, Philippe] [Missae sex] (Madrid:Johannes Flandre, 1598) [RISM R1937].

[Victoria, Tomás Luis de] [Motecta festorum totius anni] (Rome: Alessandro Gardano, 1585) [RISM V1433].

The cathedrals of Toledo and Córdoba, and to a lesser extent Tarazona, were all major institutions with considerable financial resources. As is clear from the

34 Juan Rafael Vázquez Lesmes, 'La capilla de música de la catedral cordobesa', Boletín de la Real Academia de Córdoba, de Ciencias, Bellas Letras y Nobles Artes, 57/110 (1986), pp. 113-141.

35 See Appendix 2 below.

36 The book would have been the Liber primus missarum (Paris: Nicholas du Chemin, 1566); for the payment by the chapter see Monumentos de la Música Española Xxxvi (Barcelona, 1978), p. 59 . 
inventories of the collegiate churches in Daroca and Orihuela, smaller institutions with a college of canons some of whom could perform polyphony might possess a reasonable collection of printed books of music. Daroca, which lies to the south of Zaragoza, possessed a large collection of chant books together with two choirbooks of masses and a manuscript of magnificats by Morales, and partbooks containing motets by Guerrero. ${ }^{37}$ In Orihuela, in the province of Alicante, an inventory of the books made before 1562 , just two years before the church was raised to cathedral status, records a copy of the Liber quindecim missarum, the two books of masses by Morales in either the Dorico or Moderne edition, masses by Pierre Colin, and four sets of partbooks containing magnificats and motets by Festa, Ruffo, and Crequillon together with some manuscripts of polyphony. ${ }^{38}$ None of these books survive.

Cuenca Cathedral provides an example of a less prestigious cathedral whose library of sixteenth- and seventeenth-century printed music, most of which has almost completely disappeared, can only be re-constructed from a range of documentary evidence of various kinds. ${ }^{39}$ Rugged and somewhat remote, Cuenca lies in the Castille-La Mancha region of south-eastern central Spain; the cathedral itself is one of a number in the ecclesiastical province of Toledo. During the later Mediaeval period, when the city had reached the height of its wealth, music in the cathedral prospered, and documentation from the latter part of the century reveals that books of music were purchased and copied on a regular basis. By 1637, when the carpenter Juan de Alarcón was ordered by the cathedral chapter to make a chest or cupboard ('caxon') for them, there must have been a considerable collection, but most of it has disappeared. ${ }^{40}$ From payment records it is known that although most of the books were bound by local booksellers, the majority were purchased in major centres of the book trade such as Seville and Medina del Campo. ${ }^{41}$

37 Pedro Calahorra Martinez, 'Dos inventarios de los siglos Xvi y XviI en la collegial de Daroca y dos pequeñas cronicas darocenses', Revista de musicologia, 3 (1980), pp. 1-43, at pp. 7-9: "La primera y segunda parte de Morales, en dos cuerpos", presumably either the Moderne or Dorico mass volumes, "otro libro de magnificats de Morales, escrito de mano", and "Los motetes de Guerrero, en cinco cuerpos".

38 Esperanza Rodríguez-García, 'El repertorio polifónico de la colegiata de Orihuela según un inventario de mitad del siglo Xvi', Anuario musical, 63 (2008), pp. 3-24.

39 For what survives see Restituto Navarro Gonzalo, Catálogo musical del Archivo de la Santa Iglesia Basílica de Cuenca (Cuenca: Inst. de Música Religiosa, 2/1973), pp. 329-337.

40 Martínez Millán, Historia musical de la catedral de Cuenca (Cuenca: Diputación Provincial de Cuenca, 1988), p. 62.

41 Martínez Millán, Historia musical, p. 61. 
There were also 'donations'. Following a common practice, already noted in connection with the cathedrals in Burgos and Córdoba, both Morales and Victoria sent copies of their latest publications to the chapter in the expectation that they would be financially rewarded. In October 1545 the chapter agreed to pay Morales for the two printed books of Masses he had sent; these, which were already bound, presumably to give the appearance of a more handsome donation, must have been copies of the choirbooks published by Valerio Dorico in Rome in the previous year. ${ }^{42}$ Similarly, in 1600 Victoria sent the folio edition of his masses, magnificats and other liturgical settings recently published by the Typographia Regia in Madrid for which the chapter also agreed to pay him in the following year. ${ }^{43}$ Although none of these acquisitions has survived, a substantial collection of early editions of works by Palestrina is still in Cuenca; it does not appear in the inventories, and its provenance is unknown. Among this mixture of partbooks and choirbooks is the Torniero and Donangelo edition of the Hymni totius anni of 1590, and assorted sets of Venetian editions of some of the books of masses. Many of these volumes, now in poor condition and incomplete, show clear signs of use over a long period of time.

Damage through use is a frequently-encountered feature of the printed books of music that survive in Spanish ecclesiastical libraries and archives. An extreme instance is that of copies of the Dorico edition of the second book of Morales' masses and a Craesbeeck edition of masses by Cardoso which were dismembered in order to patch up the organ of the Iglesia-colegiata in Pastrana. ${ }^{44}$ Also common is the total destruction of a complete collection as part of the exacting toll paid by many towns and cities as a result of the ravages of the many wars and civil disturbances that mark the troubled history of the peninsula from the War of Independence to the Spanish Civil War. One of the most dramatic sixteenth-century episodes of this kind took place as the result of the victory of the combined English and Dutch fleets over the Spanish at Cádiz, and the subsequent sack of the city itself on 21 June 1596. This devasting

42 See Martínez Millán, Historia musical, p. 54: "dos libros que enviaba para la dicha Iglesia de Misas estampadas y por él compuestas e bien encuadernadas”, presumably RISM M3580-M3581. The Scotto and Gardano part-book editions are to be excluded here since Spanish inventories usually refer to a set of five books as 'cincos libros'. For these editions of the Morales masses see Suzanne G. Cusick, Valerio Dorico, Music Printer in SixteenthCentury Rome (Ann Arbor: University Microfilms International, 1981), pp. 171-172.

43 Tomas Luis de Victoria, Missae, Magnificat, motecta, psalmi... (Madrid: Ex typographia regia/Joannes Flandre, 1600) [RISM V1435]. See Martínez Millán, Historia musical, p. 106, "por unos Libros de Canto que envió al Cabildo que eran de Misas, Salmos, Salves y otras cosas y a dos y tres coros de Canto de Organo".

44 See Martinez-Gil, Catálogo de música, p. ix. 
assault, carried out by troops under the Earl of Essex, was one of the most decisive military successes of the long conflict between England and Spain, a conflict which effectively stretched from the Earl of Leicester's expedition to the Netherlands in support of the States-General in 1585 to the Treaty of London in $1604 .{ }^{45}$ Reports of the scale of destruction vary. As a major institution, the cathedral would undoubtedly have housed a collection of liturgical books and music both printed and manuscript, including choirbooks containing both chant and polyphony. These would surely have been seen by the soldiery as no more than the tools of a despised religion. Together with much else, including images and vestments, they were presumably destroyed when the building was torched by the occupying soldiers before leaving the city. ${ }^{46}$ A heavily-damaged antiphoner, removed during the sack, was presented shortly after Essex's return to King's College, Cambridge, where it was displayed to visitors as war booty during the early seventeenth century. ${ }^{47}$ Books from the Jesuit College did not necessarily share the same fate, even though it too was razed to the ground. Here Edward Doughtie, official chaplain to the expedition and later Dean of Hereford, selected a number of volumes from the library and brought them back to England. ${ }^{48}$ A sixteenth-century choirbook containing plainchant, now in the National Library of Scotland in Edinburgh, was also removed from the Jesuit College during the raid. ${ }^{49}$

45 For overviews see Julian S. Corbett, The successors of Drake (London: Longmans, Green and Company, 190o), and R.B. Wernham, The return of the Armada. The last years of the Elizabethan war against Spain, 1595-1603 (Oxford: Clarendon Press, 1994). For different perspectives see Magdalena de Pazzis Pi Corrales, 'The view from Spain: Distant images and English political reality in the late sixteenth century', and Bernardo J. García García, 'Peace with England, from convenience to necessity, 1596-1604', both in Anne J. Cruz (ed.), Material and symbolic circulation between Spain and England, 1554-1604 (Aldershot: Ashgate, 2008), at pp. 13-27 and 135-149 respectively.

46 Castro, Historia del saqueo, p. 7.

47 King's College, Cambridge, Ms. 41; see Montague R. James, A Descriptive Catalogue of the Manuscripts other than Oriental in the Library of King's College, Cambridge (Cambridge: Cambridge University Press, 1895), pp. 67-68, and Iain Fenlon, 'A Spanish Choirbook and some Elizabethan Book Thieves', in Jean Michel Massing and Nicolette Zeeman (eds.), King's College Chapel 1515-2015: Art, Music and Religion in Cambridge (London and Turnhout: Harvey Miller, 2014), pp. 181-198 and 383-385.

48 Percy S. Allen, 'Books brought from Spain in 1596', English Historical Review, 31 (1916), pp. 6o6-610, at pp. 6o9-610, gives a figure of seventeen. However, only nine of the volumes now in Hereford contain an inscription indicating that they were removed from Cádiz.

49 Edinburgh, National Library of Scotland, MS 1905; see National Library of Scotland: Catalogue of Manuscripts Acquired since 1925, 8 vols. to date (Edinburgh: Her Majesty's Stationery Office, 1938-92), vol. 2, p. 18, and Fenlon, 'A Spanish Choirbook', p. 188. 
Although the destruction of the cathedral in 1596 inevitably resulted in much loss of documentation, some chapter acts do survive from the 1580 , and these reflect an active musical life and record the acquisition of a number of music books that were probably in use at the time of Essex's expedition. ${ }^{50} \mathrm{On}$ 9 November 1583 Guerrero sent "un libro de música", and at about the same time two sets of printed partbooks were also acquired in Rome by the Archdeacon of Cádiz and sent to the cathedral. In 1585 the chapter acquired a book of music by Victoria, and in 1589, it bought two further books of music by Guerrero. Rebuilding of the cathedral began almost immediately after the sack, and soon books of printed music were acquired including two by Victoria (one of which was his Officium defunctorum), and unspecified titles by Duarte Lobo and Vivanco. None of these have survived; the one that has, Guerrero's Liber vesperarum of 1584 , may well have been sent to the cathedral, like the others noted in the chapter acts, by the composer himself, in the hope of financial reward. ${ }^{51}$

A similar instance of the re-invention of a collection following destruction is that of Segovia Cathedral, where the church itself was largely destroyed during the revolt of the comuneros in the early $15^{20}$ s, and the foundation stone of a 'new' cathedral was then laid in 1525 . This period of reconstruction of the fabric coincides with the organization and expansion of its musical chapel..$^{52}$ Although it is clear that a substantial collection of polyphony was assembled in the process, only a part of it still survives. ${ }^{53}$ Its extent in the early seventeenth century can be recovered from the only known inventory, compiled not long after Juan de Leon was appointed maestro de capilla in 1620. Among the books listed which still survive are the Masses and Magnificats by Vivanco, ${ }^{54}$

50 See Pablo Antón Solé, 'Bibliotecas y bibliófilos gaditanos', Archivo Hispalense, 176 (1974), pp. 41-58; Máximo Pajares Barón, Archivo de música de la Catedral de Cádiz (Granada: Junta de Andalucía, 1993), from which the following notices are taken.

51 Libro de Polifonía 1 (Registro, 1/1-45); see Pajares Barón, Archivo de música, pp. xvi-xvii. The copy of Francisco Guerrero: [Liber vesperarum] [Rome: Domenico Basa/ Alessandro Gardano, 1584], which is not recorded in RISM G4873, lacks its title page and a number of other folios.

$5^{2}$ For which see the extracts from the chapter acts published in José López-Calo, Documentario musical de la catedral de Segovia, I: Actas Capitulares (Santiago: Universidade de Santiago de Compostela, 1990). For the history of music in the cathedral in general see José López-Calo, La música en la catedral de Segovia, 2 vols. (Segovia: Diputación Provincial de Segovia, 1988-1989).

53 For a complete catalogue see Hilario Sanz y Sanz, Catálogo de cantorales y libro de coro (Segovia: Gabel, 1972).

$54 \quad$ RISM V2250 and V2249. 
the Magnificats by Aguilera de Heredia, ${ }^{55}$ and two books of music by Guerrero, namely the Liber vesperarum and the Masses. ${ }^{56}$ This leaves some eleven titles which were present in 1620 but which have subsequently been lost:

Esquivel, Missarum...liber primus (Salamanca: A. Taberniel, 1608). [RISM E825].

Esquivel, Motecta festorum, (Salamanca, 1613). [RISM E826].

Guerrero, Liber primus missarum (Paris, N. du Chemin, 1566). [RISM G4870].

Lobo, Liber primus missarum (Madrid: J. Flandre, 1602). [RISM L2588]

Morales, Missarum liber primus (Rome: V. \& L. Dorico, 1544). [RISM $\left.\mathrm{M}_{3580}\right]^{57}$

Morales, Missarum liber secundus (Rome: V. \& L. Dorico, 1544). [RISM $\mathrm{M} 3582] .{ }^{58}$

Morales, [Magnificats] [Not identifiable].

Palestrina, Missarum liber tertius (Rome: heirs of V. \& A. Dorico, 1570). [RISM].

Palestrina, Hymni totius anni (Venice:A. Gardano, 1589). [RISM P738].59

Palestrina, [four books] [i.e. partbooks].

Rogier, Missae sex (Madrid:J. Flandre, 1598). [RISM R1937].

In the case of the collegiate church of Santa María de la Encarnación ('la Mayor') in Ronda, it is a wonder that so much of the interior decoration and the possessions of the church has survived at all. Largely destroyed by an earthquake in 1580 , the church was then reconstructed; remarkably, given its later history, it still preserves its elaborately carved choirstalls. During the Spanish Civil War, Ronda was fiercely Republican, and outbursts of anti-clerical feeling were common during the 'Red Terror' of 1936 before the town fell to the Nationalists. These not only took the form of violence against the clergy, but also the destruction of churches, convents, and their contents. In June 1937,

55 RISM A450.

56 Liber vesperarum... (Rome: Domenico Basa/Alessandro Gardano, 1584) [RISM G4873]; either the Liber primus missarum (Paris: N. du Chemin, 1566) [RISM G4870] and/or the Missarum liber secundus (Domenico Basa/Francesco Zanetto, 1582) [G4872]. All three are choirbooks.

57 This could also be the Moderne edition, Lyon 1546 [RISM M3581].

58 This could also be the Moderne edition, Lyon 1551 [RISM M3583].

59 This could be either the 1590 edition (heirs of G. Scotto), or that of 1589 (G. Turniero \& B. Donangelo). 
Miguel Artigas, who had been director of the Biblioteca Nacional in Madrid until the outbreak of war, published an open letter to the 'Hispanists of the world' condemning the destruction of museums, libraries, and archives under Republican control. ${ }^{60}$ Since, as a collegiate church, Santa Maria de la Encarnación, had been well equipped to perform polyphony, it seems likely that a considerable collection of books of music was destroyed along with the church's Baroque organ. Just one survived as a result of the prompt actions of the sacristan who succeeded in hiding it before the looting of the church began: the unique copy of the printed edition of Juan de Esquivel Barahona's psalms, hymns and magnificats printed in distant Salamanca in $1613 .{ }^{61}$

Of all the instances that could be cited of the loss of books of polyphony from Spanish cathedrals and churches, none can compare with the disastrous reception history of the extraordinary library assembled by Fernando Colón, son of Cristoforo Colombo. Following a brief period as a colonial administrator in Hispaniola (Cuba), Colón returned to Spain, where he devoted much of his time to acquiring and cataloguing a collection of printed books, prints, and manuscripts. This, with some 15,370 volumes a small number of which had been inherited from his father, was unparalleled for its time in both size and scope. In his will of 3 July 1539 Fernando Colón bequeathed his library to his nephew Luis Colón, on condition that he allocate 100,000 maravedís per annum towards both its upkeep and further acquisitions. Should his nephew fail to do this, the library would pass to the cathedral, together with sufficient funds for the same purpose. In fact, the chapter quickly expressed its interest following Colón's death, and when it became clear that Luis Colón had no intention of meeting his obligations, the chapter was ready to claim it. A protracted legal wrangle ensured, but eventually in March $155^{2}$ the court decided in the cathedral's favour, and preparations were made to receive the books and inventory them. This process took almost a year, which is hardly surprising given the size of the collection, but it was then several decades before Colón's collection was housed. Various inventories compiled over the course of the sixteenth century

6o Sebastiaan Faber, Anglo-American Hispanists and the Spanish Civil War. Hispanophilia, Commitment, and Discipline (New York: Palgrave Macmillan, 2008), p. 10.

61 Juan (de) Esquivel Barahona, Psalmorum, hymnorum, magnificarum et b[eatae] Mariae quatuor antiphonarum de tempore, necnon et missarum tomus secundus (Salamanca: Francisco de la Cea Tesa, 1613). Robert J. Snow, The 1613 Print of Juan Esquivel Barahona (Detroit: Information Coordinators, 1978), pp. 10-36; Higino Anglés, Cataleg del manuscrits musicals de la collecció Pedrell (Barcelona: Institut d'Estudis Catalans, 1921), pp. 25-26; Clive Walkley, Juan Esquivel: A Master of Sacred Music during the Spanish Golden Age (Woodbridge: Boydell and Brewer, 2010). 
reveal that many books were withdrawn or destroyed. Further losses were sustained over the centuries, and even up to modern times, and only a fraction of the Biblioteca Columbina, as it came to be known, now remains in Seville. The separate collection in the Biblioteca Capitular did not fare any better. Here the earliest surviving inventory to include books of music dates from 19 February 1588 , they were re-inventoried in the years $1603-1605$, and then again in 1618 , following the death of the maestro de capilla and the appointment of his successor. ${ }^{62}$ Nearly all the printed books listed in these inventories have been lost except for copies of Aguilera de Heredia's volume of magnificats, and Duarte Lobo's masses. ${ }^{63}$

Notwithstanding these losses, enough survives of both the library and Colón's meticulously-kept records to provide a good deal of useful information. From the documentation it is clear that many of his books were acquired not only from booksellers and agents all over Europe, but were bought personally in the course of four extended trips to Italy and Northern Europe. It is possible to reconstruct Colón's book-buying activities with some precision, since he entered the details of his acquisitions in his Registra, which were to be used in conjunction with their respective alphabetical indexes - the Abecedarium and the Supplementum. Taken together with the notes recording place of purchase and sometimes the price paid that are sometimes to be found on the fly-leaves of the relatively small number of surviving books from his library, it is possible to piece together a reasonably detailed impression of the four book-buying 'voyages' that Colón made outside Spain. These began in September 1512 with a trip to Rome, where he remained for almost a year. Subsequent forays took him not only back to Italy, but also to the Low Countries, to a number of German-speaking cities, then to Basel, London, and finally France. Most (though not all) of his French books, including some printed

62 See Carmen Álvarez Márquez, El mundo del Libro en la Iglesia Catedral de Sevillas en el Siglo XVI (Seville: Diputación Provincial, 1992), particularly pp. 249-251 where six inventories, drawn up in 1522, 1552, 1588, 1592 (two) and 1596 are published; Ros Fábregas, 'Libros de música', no. 54 and, for the most recent account of music at the Cathedral, Juan Ruiz Jiménez, La librería de canto de órgano. Creación y pervivencia del repertorio de Renacimiento en la actividad de la cathedral de Sevilla (Granada: Junta de Andalucia, 2007), pp. 21-33, with transcriptions of various inventories in Apéndice 1.

63 Sebastian Aguilera de Heredia, Canticorum Magnificat Beatissime Virginis Deiparae Mariae (Zaragoza: Cabarte, 1618) [RISM A450], and Duarte Lobo, [Liber Missarum] (Antwerp: Officina Plantiniana, 1621) [RISM L2591]. A copy of Francisco Guerrero, Motecta...quae partim quaternis... (Venice: Vincenti, 1597) [RISM G4877] now in the Biblioteca Columbina is presumably from the Cathedral library. 
music, were acquired on this fourth and last of these journeys. Had Colón's library been preserved intact, it would be without doubt the most important repository of early sixteenth-century printed music to have survived anywhere. Even in its present, much depleted condition, it is crucial for our understanding of the earliest phase of music-printing and publishing in Europe. For it is clear from both the surviving copies and the records of his library, that Colon owned a copy of nearly every Italian and French music book now known to have been published up to 1535 , including a considerable number that have not survived in even a single examplar. The general level of accuracy in Colón's catalogues is high, and there is no reason to suspect that his references to titles that have not been identified are 'ghosts'. On the contrary, the details recorded in the Columbina catalogues are invaluable for resolving some of the difficulties caused by the poor survival rate of the books themselves. Two dramatic examples of lost music books recorded in the Biblioteca Columbina catalogues make the point. In the 199os, the contract for the Libro primo de musica de la salamandra, printed in Rome in 1526 , was discovered, thus confirming the printing of a title of which Colón owned a copy but of which no surviving examples are known. ${ }^{64}$ Similarly, a copy of Piéton's penitential psalm settings, recently identified in the library of the Collegiate Church in Castell'Arquato, is a book that was owned and catalogued by Colón but had previously been thought to be lost. ${ }^{65}$

The example of Colón's bibliophilia, which extended to the accumulation of manuscripts and prints as well as printed books, is exceptional by any standards. Nonetheless the example which he provides of travelling outside Spain in order to build up a library was a common one. Other collections of printed books, sometimes including music, were similarly assembled by private individuals and bequeathed to ecclesiastical institutions but are now lost. Juan Bernal Diaz de Luco, Bishop of Calahorra, one of the principal Spanish delegates to the Council of Trent, collected a sizeable library including books of music which he left to his cathedral on his death in $1556 .^{66}$ This included partbooks of motets by Josquin and Guerrero (at this date

64 For the printing contract which confirms the existence (and hence the accuracy of Colón's catalogue entry for it) see Bonnie J. Blackburn, 'The Printing Contract for the Libro primo de musica de la salamandra (Rome, 1526)', Journal of Musicology, 12 (1994), pp. 345-356.

65 Laurent Guillo, 'Les motets de Layolle et les Psaumes de Piéton: Deux nouvelles éditions Lyonnaises du seizième siècle', Fontes artis musicae, 32 (1985), pp. 186-191.

66 T. Marín Martinez, 'La biblioteca del obispo Juan Bernal Diaz de Luco (1495-1556)', Hispania sacra, 5 (1952), pp. 263-326, and 'La biblioteca del obispo Juan Bernal Diáz de Luco, Lista de autores y obras', Hispania sacra, 7 (1954), pp. 47-84. 
presumably the Montesdoca edition), and the now familiar folio choirbooks of masses by Morales printed in either Rome or Lyon. ${ }^{67}$ All these have now disappeared. ${ }^{68}$ Such examples could be multiplied, and represent just one route by which repertory, some of it bought abroad, could be accumulated by men of substance. ${ }^{69}$ Another conduit for the acquisition of music from abroad was provided by those of more limited means - clerics, musicians and chapelmasters - who also travelled and in the process acquired books for the use of their institutions. ${ }^{70}$

From this selective account of some of the losses of printed music sustained over the centuries by Spanish church institutions three significant conclusions emerge. Firstly, the impression created by a reconstruction of the lost books of polyphony is remarkably consistent. Andrea Antico's Liber quindecim missarum was widely distributed throughout the peninsula and, encouraged by the traditional placing of the coro and its associated furnishings including a lectern from which polyphony would have been performed, established the printed choirbook within the Iberian trade. As might be expected, the core repertory of Spanish and Portuguese choral institutions mapped onto that of Catholic Europe as whole with the music of Palestrina particularly prominent. Not surprisingly, the music of Guerrero and Victoria was to be found everywhere, and to lesser extent Morales, much of it also in choirbook form. The somewhat 'closed' market serviced by local printers and publishers ensured that liturgical music by Vivanco, Esquivel, and Aguilera, while distributed throughout Iberia, did not travel elsewhere. Even here there were regional patterns as with Aguilera de Heredia's Canticum Beatissime Virginis, where both the surviving copies as well as lost ones were concentrated in the area around

67 Francisco Guerrero, Sacrae cantiones (Seville: Martin Montesdoca, 1555).

68 Juan Bernal also owned Moderne's edition of one of the Mottetti del fiore produced between 1532 and 1542, and the partbooks of Gardano's two collections of the Mottetti del frutto. His donation of music to Calahorra Cathedral was the largest to be made anywhere by a sixteenth-century ecclesiastic; see Ros Fabrégas no. 42.

69 For the modest donation of Canon Lancis to the Cathedral of La Seo in Zaragoza see Tess Knighton, 'La circulación de la polifonía europea en el medio urbano: libro impresos de música en la Zaragoza de mediados del siglo Xvı' in Andrea Bombi, Juan José Carreras and Miguel Ángel Marín (eds.), Música y cultura urbana en la edad moderna (Valencia: Universitat de Valencia, 2005), pp. 337-349.

70 For the purchases of books of music by the canons of the monastery of Santa Cruz in Coimbra see Owen Rees, Polyphony in Portugal c.1530-c.1620. Sources from the Monastery of Santa Cruz, Coimbra (New York and London: Garland, 1995), pp. 93-94, and for Tarazona Owen Rees, 'Roman Polyphony at Tarazona', Early Music, 23 (1995), pp. 410-419. 
Zaragoza where the book was produced, or the choirbooks by Craesbeeck printed in Lisbon and rarely found outside Portugal. ${ }^{71}$

Second, while for obvious geo-political reasons both Antwerp and Venice were major centres of supply for the Spanish book trade, Lyon was also of considerable importance, particularly during the first half of the century when the presses of Jacques Moderne were at work. ${ }^{72}$ This may partly be explained by the economic benefits of the Lyon trade in general, which by 1545 supported twenty-nine bookshops and sixty-five printing houses. ${ }^{73}$ The city's geographical position was also crucial; proximity to the Loire provided easy access to the Atlantic, and from there to the sea routes that connected Nantes to the ports of the Cantabrian coast. ${ }^{74}$ From Bilbao, bales of books from Lyon were transported overland via an internal road system which linked it to Valladolid, Burgos, Salamanca, and Medina del Campo, home of the most important of the Spanish book fairs. ${ }^{75}$ Contacts between merchants operating both there and at the fair in Lyon, the twin poles of an important commercial artery, were strong, and many traders worked in both places. ${ }^{76}$ This is one important route for the transportation of books from France to the peninsula. ${ }^{77}$ Others were transported down the Rhône to the Mediterranean and then on to Barcelona and Valencia, the two most important ports on the eastern seaboard. ${ }^{78}$ Booksellers in both cities bought books from Lyon directly as well as

71 A number of Craesbeeck's editions, including music by Cardoso and Garro, were originally in the library of Toledo Cathedral; see Appendix 1.

72 For the general picture see Christien Péligry, 'Les éditeurs lyonnais et le marché espagnol aux XVI et XVII ${ }^{\mathrm{e}}$ siècles', in Livre et lecture en Espagne et en France sous l'Ancien Régime (Paris: Éditions ADPF, 1981), pp. 85-93.

73 Richard Gascon, Grand commerce et vie urbaine aux XVIe siècle: Lyon et ses marchands (environs de 1520-environs de 1580) (Paris: S.E.V.P.E.N., 1971), vol. I, p. 307.

74 Henri Lapeyre, Un famille de marchands, les Ruiz (Paris: Colin, 1955), pp. 170-179. Malcolm Walsby, The Printed Book in Brittany, 1484-16oo (Leiden: Brill, 2011).

75 Marta de la Mano González, Mercadores e impresores de libros en la Salamanca del siglo XVI (Salamanca: Ediciones Universidad de Salamanca, 1998), pp. 200-204.

$7^{6}$ See many of the documents published in Felipe Ruiz Martín, Lettres marchandes échangées entre Florence et Medina del Campo (Paris: S.E.V.P.E.N., 1965).

77 See Lapeyre, Une famille des marchands, pp. 567-573, which deals with French printerpublishers and their factors operating in Medina del Campo in the second half of the century.

$7_{8}$ Gascon, Grand commerce et vie urbaine, vol. I, pp. 104-106, 118-119, 164-165; Miguel Peña Diaz, Cataluña en el Renaciemento: libros y lenguas (Barcelona, 1473-160o) (Lleida: Milenio, 1966), pp. 96-103, and Philippe Berger, Libro y lectura en el Valencia de Renacimiento (Valencia: Edicions Alfons el Magnànim, Institució Valenciana d'Estudis i Investigació, 1987), vol. I, pp. 272-273. 
commissioning editions from printers working there. ${ }^{79}$ It was Moderne's success in making use of these existing networks that helps to explain the widespread distribution of his editions in Spain; it was a specific geography that determined commercial, editorial and even authorial decisions.

A third general conclusion concerns the extraordinary persistence of so much of the repertory. From the material condition of many of the surviving books, where generations of singers have added not only music but also signatures and dates, it is clear that some volumes were in continuous use from the moment of their acquisition until as late as the Second Vatican Council. Similarly, there are plenty of instances of printed books being used as exemplars for the copying of much later manuscript choirbooks, presumably as the originals fell into decay. Here, as elsewhere, the picture is of constant renewal of established repertory on the one hand, in tandem with depletion and loss on the other.

\section{Appendix 1}

\section{Toledo Cathedral: Lost Books Once Recorded as Part of the Collection}

References are to Michael Noone, 'Printed Polyphony Acquired by Toledo Cathedral, 1532-1669', in Iain Fenlon and Tess Knighton (eds.), Early Music Printing and Publishing in the Iberian World (Kassel: Edition Reichenberger, 2006), pp. 241-274 (=Noone 2006); and Emilio Casares (ed.), Francisco Asenjo Barbieri. Biografías y documentos sobrer música y músicos españoles (Legado Barbieri), 2 vols. (Madrid: Fundación Exterior, 1986) (=Casares 1986).

1. Liber quindecim missarum (Rome: A. Antico, 1516) [RISM15161] (Noone 2006, p. 249).

2. Aguilera de Heredia: Canticum Beatissime Virginis (Zaragoza: P. Cabarte, 1618) [RISM A450] (Noone 2006, p. 262). Received by the chapter on 15 May 1619. Binding repaired in October 1688. (Inventories of 1649, c.1680 and 179o, by which time 'muy maltratado').

79 For Guardiola see Miguel Peña, 'Librería y edicíon en la Barcelona des xvi: el librero -editor Joan Guardiola', Manuscrits, 9 (1991); Miguel Peña, 'Un librero-editor en la Barcelona del xvi. Juan Guardiola', in José Hinojosa Montalvo and Jesús Pradells Nadal (eds.), 149o: En el umbral de la modernidad. El mediterraneo europeo y las cuidades en el transito de los siglos $X V-X V I$ (Valencia: Generalitat Valenciana-Consell Valencià de Cultura, 1994), vol. 2, pp. 312-331; Peña Diaz, Cataluña en el Renacimiento, pp. 97-100 and 201. 
3. Cardoso: Cantica Beatae Mariae Virginis (Lisbon: P. Craesbeeck, 1613) [RISM C1038] (Casares 1986, I, p. 68; Noone 2006, pp. 262-263). Acquired in 1637. (Inventory of c.1680).

4. Cardoso: Missae quaternis...liber primus (Lisbon: P. Craesbeeck, 1625) [RISM C1039] (Casares 1986, I, p. 68; Noone 2006, pp. 262-263). Acquired in 1637. (Inventory of c.1680).

5. Carpentras: Liber primus missarum (Avignon: J. de Channay, 1532) [RISM G1571] (Noone 2006, p. 243). (Possibly the Carpentras volume listed in the inventory of 1793).

6. Garro: Missae quatuor (Lisbon: P. Craesbeeck, 1609) [RISM G430] (Rees 2000; Noone 2006, p. 261). Acquired after 16oo. (Inventory of 1649).

7. Garro: Francisco Garri Natione Navarri...opera aliquot (Lisbon: P. Craesbeck) [Not in RISM] (Rees 2000; Noone 2006, p. 261). Acquired after 1600. (Inventories of 1649 and c.1680).

8. Guerrero: Motetta (Venice: A. Gardano, 1570) [RISM G4871] (Casares 1986, I, p. 245; Noone 2006, pp. 254-255), where the possibility that this was the Sacrae cantiones (Seville: Martin de Montesdoca, 1555), [RISM G4867] is raised. Purchased in 1583. (Inventories of 1600 and 1649).

9. Guerrero: Motecta...Liber secundus (Venice: G. Vincenti, 1589) [RISM G4875] (Noone 2006, p. 257). Purchased in 1594. (Inventories of 1600 and 1649).

10. Guerrero: Canciones y villanescas espirituales (Venice: G. Vincenti, 1589) [RISM G4876] (Noone 2006, p. 257). Purchased in 1594. (Inventories of 1600 and 1649).

11. La Hèle: Octo missae (Antwerp: C. Plantin, 1578) [RISM L285] (Noone 2006, p. 253). Acquired in March 1582. (Inventories of 1600 and 1649).

12. D. Lobo: Cantica B. Mariae virginis (Antwerp: Plantin/Moretum, 1605) [RISM L2590] (Noone 2006, p. 264). (Included in the inventory of 1649, but payment not settled until 1655).

13. D. Lobo: Liber missarum (Antwerp: Plantin/Moretum, 1621) [RISM L2591] (Noone 2006, p. 264). Payment made on 14 June 1655.

14. Mogavero: Lamentationem Jeremiae prophete (Venice: A. Vincenti, 1623) [RISM M2920] (Noone 2006, p. 263). Acquisition date unknown. (Inventories of c.1680 and 1793).

15. Morales: Missarum liber primus (Rome: V. \& L. Dorico, 1544) [RISM M3580] (Noone 2006, pp. 249-250). Probably purchased from Morales in 1545. (Inventory of 1563 , described as old and worn; not in inventory of 1580 ).

16. Morales: Missarum liber primus (Rome: V. \& L. Dorico, 1544, or Lyon: J. Moderne, 1546) [RISM M3580 or M3581] (Noone 2006, p. 251).

17. Morales: Missarum Liber secundus (Rome: V. \& L. Dorico, 1544) [RISM M3582] (Noone 2006, pp. 249-250). Probably purchased from Morales in 1545. (Inventory of 1563 , described as old and worn; not in inventory of 1580). 
18. Morales: Missarum liber secundus (Rome: V. \& L. Dorico, 1544, or Lyon: J. Moderne, 1551) [RISM M3582 or M3583] (Noone 2006, p. 251).

19. Rogier: Sacrarum modulationem...liber primus (Naples: Stelliolae, 1595) [RISM R1936] (Casares 1986, I, p. 412; Noone 20o6, pp. 265-266). Payment was made on 10 July 1663. (Inventory of 1793).

20. Victoria: Cantica B. Virginis vulgo Magnificat (Rome: D. Basa, 1581) [RISM V1430] (Noone 2006, pp. 251-252). (Inventories of 1600, 1649, and c.1680, but not that of 1790).

21. Victoria: Hymni totius anni (Rome: D. Basa, 1581) [RISM V1428] (Noone 2006, pp. 251-252). (Inventories 1600, 1649, and c.1680, but not that of 1790).

22. Victoria: Missarum libri duo (Rome: A. Gardano, 1583) [RISM V1431] (Casares 1986, I, p. 497; Noone 2006, pp. 255-256). Acquired in 1585. (Inventories of 1600 , 1649 and c.1680).

23. Victoria: Missa...liber secundus (Rome: F. Coattino, 1592) [RISM V1434] (Casares 1986, I, p. 231, and Noone 2006, pp. 256-257). Acquired 31 July 1593. (Inventories of 16oo, 1649 and c.1680).

24. Victoria: Missae, Magnificat, motecta, psalmi (Madrid: J. Flandres, 160o) [RISM V1435] (Noone 2006, pp. 259-26o). Acquired late 1600 or early 1601 and paid for on 11 July 1601. (Inventories of 160o(?), 1649 and c.1680).

25. Vivanco: [Liber Missarum] (Salamanca: A. Taberniel, 1608). [RISM V2250] (Casares 1986, I, p. 504 and Noone 2006, pp. 264-265). Acquired in 1658 from Andrés Roldán, sacristan of the church of Colmenar de Oreja.

26. Vivanco: Liber magnificarum (Salamanca: A. Taberniel, 1607) [RISM V2249] (Casares 1986, I, p. 504, and Noone 2006, pp. 264-265). Acquired in 1658 from the same source as no. 25, and recorded as lost in 1795 .

27. Vivanco: [Liber motectorum] (Salamanca: A. Taberniel, 1610) [RISM V2251]. Acquired in 1658 from the same source as no. 25 .

\section{Appendix 2}

\section{Córdoba Cathedral: Inventory of $1629^{80}$}

Inventario de los libros de canto de órgano que esta Santa Iglesia Cathedral de Córdoua tiene, los quales están a cargo del maestro de Capilla Gabriel Díaz, presbítero, capellán perpetuo de la capilla de Santa Ignnés...en el dicho día veinte y seis días del mes de abril de mill y seiscientos y veinte y nueve años, el dicho señor Visitador General desta

80 "Ynbentario de los ornamentos...fecho en Córdoua en el mes de nouienbre años de $1628 \ldots$..., fols. $15^{1 r-154 r}$. I am grateful to the Cathedral archive for allowing me to use this typescript transcription of the inventory made by Don Nieto Cumplido. 
ciudad, prosiguiendo su visita de la dicha Santa Yglesia, mandó pedir y pidió quenta a Joan de Montiel, maestro de Capilla de la dicha Santa Yglesia, de los libros de canto de órgano que an estado a su cargo y por otro inventario que se hizo a el maestro Joan de Riscos y vn memorial que ay firmado del dicho Joan de Montiel, maestro susoducho, se le fueron pidiendo los dichos libros y se hizo el dicho inventario en la forma e manera siguiente:

\section{Para MISAS}

[1] Primeramente el libro de Joan [sic] Jusquin.

[2] Primera y segunda parte de Morales.

[3] Primera y segunda parte de Guerrero.

[4] Primera y segunda parte de Victoria.

[5] Primera parte de Alonso Lovo.

[6] Un libro de mano de dos misas y Lamentaciones de Zevallos.

[7] Un libro de ocho misas, asperges y motetes de Duarte Lobo que se trajo de Almagro en septiembre de 1603 años, impresso en Lisboa. [later addition]

[8] Un libro grande de mano enquadernado en pergamino con dos misas estrangeras.

[9] Un libro donde está la missa de mi, fa, la, fa sol la, de mano.

[10] Un libro de mano grande con tablas negras con Lamentaciones y algunas misas.

[11] Otro libro de misas de Lovo, portugués.

[12] Otro libro de misas de Briceño.

[13] Dos juegos de libretes, uno de a ocho libretes, y el otro de a nueve. De los unos es autor Luis de Victoria, y de los otros un autor italiano que fue organista en la Santa Iglesia de Milán, en los quales hay misas, motetes, magnificas y psalmos de a ocho y doce voces. Se compraron en marzo de 1664 [!] [=1604?] [later addition]

\section{Libros para las visperas}

[14] Un libro de Zevallos con psalmos y himnos y magnificas.

[15] Un libro de Navarro con psalmos y himnos y magnificas.

[16] Un libro de himnos de Penestrina.

[17] Un libro grande de mano de los himnos de todo el año.

[18] Un libro de misas de Filippe Rogier.

[19] Un libro grande de bitela de hynos de canto de órgano del maestro Gerónimo Durán de la Cueva. [later addition]

[20] Un libro grande de magnificas de Bibanco.

[21] Un libro de magnificas breves de Duarte Lobo.

[22] Un libro de mano de magnificas de diversos autores.

[23] Un libro grande de tablas donde está la primera missa de Vt, re, mi, fa, sol, la.

[24] Un libro de mano donde están las Pasiones y Lamentaciones.

[25] Un libro de mano donde está el Asperges y Beatus. 
[26] Un libro grande de motetes de todo el año de Victoria.

[27] Un libro grande de mano con motetes y algunas missas.

[28] Dos libros de pocas hojas, viejos, donde está la missa de Feria.

[29] Un libro de missas de Penestrina donde está Sicut lilium. [in margin: "falta"]

[30] Un libro de Magnificas de Navarro el Moderno.

[31] Un libro de Magnificas de fr. Manuel Cardoso, impresso en Lisboa, que se trajo de Valencia en 12 de julio de 1603 años. [later addition]

[32] Un libro con Asperges y un psalmo del maestro Durán de la Cueva.

[33] Otro libro de Magnificas de Sebastián de Velasco.

[34] Dos Pasionarios de molde y un missal viejo.

[35] Otro libro de Magnificas de Morales.

\section{Libros pequeños de motetes}

[36] Dos juegos de libros de motetes de Guerrero. Fáltale la quinta parte.

[37] Dos juegos de libros de a seis de Penestrina. Falta un juego.

[38] Un juego de libros de Orlando.

[39] Un juego de libros a cinco para las procesiones que dice Ossana, etc.

[40] Medio quaderno de Vitoria con officio de Defuntos.

[41] Nueve libros de Vitoria de missas.

[42] Seis libros de motetes de don Fernando de las Ynfantas. [in margin: "faltan quatro"]

[43] Cinco libretes de motetes de Penestrina. [in margin: "faltan"]

[44] Un libro para ministriles intitulado canciones, de diferentes autores para copia de ministriles, que se compró de Acisclos de Salazar en 17 de diciembre de 1603. [later addition]

[45] Cinco libretes de Rogier, estrangero. A este juego le falta un libro [in margin: "faltan todos"]

[46] Ocho libretes de motetes de Vitoria.

[47] Otros cinco libretes de motetes de Rogieri, estrangero, y le falta uno [in margin: "faltan todos"]

[48] Un juego de nueve libretes de quartilla grande del maestro Sebastián López de Velasco.

[49] Mas ay once libretes de diferentes autores que no tienen hermanos.

Y, estando presente el dicho Gabriel Díaz, maestro de Capilla susodicho, y, aviendo visto y entendido el dicho inventario de libros de canto de órgano, se dió por entregado en todos ellos según y de la manera que aquí están escritos e inventariados y apreciados. Y confessó tenellos en su poder y se obligó de dar quenta con pago de todos los dichos libros y de cada uno dellos cumplidamente cada y cuando le sea pedido por juez competente que desta caussa pueda y deba conocer so pena de pagar el doblo y 
valor del que no entregare con el doblo y costas de cobranza. Y para ello obligó su persona y bienes muebles y raíces auidos y por aver, y dio poder a las justicias de Su Magestad, eclesiásticas y seglares, para que a ello le apremien assy como por sentencia pasada en cossa juzgada, y renunció todas y qualesquier leyes, fueros y derechos que sean en su favor y la general.Y lo firmó de su nombre el otorgante en el registro a quien yo el presente notario, doy fee que conozco, y que el dicho inventario se hizo en mi presencia y de los testigos aquí contenidos que fueron a ellos presentes, Martín Muñoz Mariscal, presbítero, y Joan de Montiel, capellán perpetuo de la dicha Santa Yglesia, y Alonso Manuel de Oblancam notario apostólico, vecinos de Córdoua. Gabriel Díaz, Don Luis de Baeza y Mosquera, notario.

\section{Identifiable Editions}

[1] Liber quindecim missarum (Rome: A. Antico, 1516) [1516/1].

[2] Missarum liber primus (Rome: V. Dorico, 1544) [M3580] or (Lyon, J. Moderne, 1546) [M3581].

Missarum liber secundus (Rome: V. Dorico, 1544) [M3582] or (Lyon: J. Moderne, 1551/2) [M3583].

[3] Liber primus missarum (Paris: N. du Chemin, 1566) [G4870].

Missarum liber secundus (Rome: D. Basa/F. Zanetti, 1582) [G4872].

[4] Liber primus (Venice: Angelo Gardano, 1576) [V1427].

Missarum libri duo (Rome: Angelo Gardano/D. Basa, 1583) [V1431].

[5] Liber primus missarum (Madrid: Typographia Regia, 1602) [L2588].

[6]

[15] Psalmi, hymni ac Magnificat totius anni (Rome: G. Torneri/F. Coattino, 1590) [N283].

[16] Hymni totius anni (Rome: G. Torneri/Donangeli, 1589) [P 737$]$.

$[17]$

[18] Missae sex (Madrid: Typographia Regia, 1598) [R1937].

[19]

[20] Liber magnificarum (Salamanca: A. Taberniel, 1607) [V2249].

[21] Cantica B. Mariae Virginis, vulgo Magnificat, quaternis vocibus (Antwerp: Plantin, 1605) [L2590]. 
[26] Motecta festorum totius anni (Rome: Alessandro Gardano/D. Basa, 1585) [V1433].

[29] Missarum liber quintus (Rome: F. Coattino, 1590) [P670].

[30] Psalmi, hymni ac Magnificat totius anni (Rome: G. Torneri/F. Coattino, 1590) [N283].

[31] Cantica Beatae Mariae Virginis (Lisbon: P. Craesbeck, 1613) [C1038].

[32]

[33] Libro de missas, motets, salmos, Magnificas (Madrid: Typographia Regia, 1628) [L2822].

[34]

[35] Mariae cantica vulgo Magnificat dicta (Lyon: J. Moderne, 1550) [M3505].

[36]

[37]

[38]

[39]

[40]

[41]

[42]

[43]

[44]

[45] Sacrarum modulationum (Naples: Typographia Stelliolae, 1595) [R1936].

[46]

[47] Sacrarum modulationum (Naples: Typographia Stelliolae, 1595) [R1936].

[48]

[49] 